\title{
Effect of intravenous terbutaline on arterial blood gas tensions, ventilation, and pulmonary circulation in patients with chronic bronchitis and cor pulmonale
}

\author{
R. A. STOCKLEY, P. FINNEGAN, AND J. M. BISHOP
}

From the Department of Medicine, University of Birmingham, Queen Elizabeth Hospital, Edgbaston, Birmingham B15 2TH, UK

Stockley, R. A., Finnegan, P., and Bishop, J. M. (1977). Thorax, 32, 601-605. Effect of intravenous terbutaline on arterial blood gas tensions, ventilation, and pulmonary circulation in patients with chronic bronchitis and cor pulmonale. Terbutaline sulphate was given intravenously to 10 patients with pulmonary vascular disease secondary to chronic hypoxia. The resting cardiac index increased after terbutaline in all the patients between 5 and $74 \%$ above the control level. The greatest change was seen in patients who had received the largest total dose. The rise in cardiac index was associated with a fall in pulmonary vascular resistance although mean pulmonary artery pressure remained unaltered. There was a significant increase in the venous admixture but this did not adversely affect the arterial oxygen tension.

The peak expiratory flow rate did not change significantly but there was an increase in ventilation from a mean value of $4.361 / \mathrm{min} / \mathrm{m}^{2}$ to $4.671 / \mathrm{min} / \mathrm{m}^{2}$.

The results show that terbutaline has little adverse effect on the pulmonary circulation or gas exchange in patients with irreversible airways disease who are in a stable state.

Terbutaline is a beta-adrenergic stimulating drug which acts mainly on $\beta_{2}$ receptors (Carlström, 1970). Its action, therefore, results in predominantly bronchodilatation and vasodilatation.

There are many studies of its bronchodilator activity in patients with reversible airways disease via the oral (Legge et al., 1971), subcutaneous (Freedman, 1971; Arner, 1970), and inhaled route (Koch, 1972; Harris, 1973).

Systemic vasodilatation has been assessed by Carlström and Westling (1970) and Arner et al. (1970). Normal subjects showed a rise in cardiac output of up to $65 \%$ after the injection of $250 \mu \mathrm{g}$ terbutaline, greatest within the first five minutes but still present at least 60 minutes after the injection and associated with a fall in peripheral vascular resistance of up to $45 \%$.

There are few studies of the circulatory effects of terbutaline in patients with lung disease. Harris (1973) found that cardiac output did not change when patients with reversible airways disease inhaled terbutaline.
Some patients with chronic airways obstruction develop pulmonary hypertension secondary to chronic hypoxaemia. If terbutaline causes vasodilatation in the pulmonary as well as the systemic circulation, it could benefit such patients by reducing the pulmonary vascular resistance and right ventricular work.

However, the effects of $\beta$-adrenergic agents on cardiopulmonary function in patients with chronic airways obstruction are complex. Halmagyi and Cotes (1959) suggested that agents affecting the pulmonary circulation may increase venous admixture, thereby reducing the systemic oxygen tension if given in such patients.

The present study was designed to investigate the possibility that terbutaline in therapeutic doses might cause beneficial pulmonary vasodilatation in patients with chronic airways obstruction and pulmonary hypertension. In addition, it was proposed to study the extent of any fall in arterial oxygen tension due to increased venous admixture effect. 


\section{Patients and methods}

Ten patients with chronic bronchitis were studied, all of whom had severe airways obstruction (Table 1) and were hypoxaemic at rest (Table 2). All ha.: suffered at least one episode of cardiac failure but none was studied sooner than six weeks after the episode when they were in a stable clinical state. All patients were receiving treatment with digoxin and diuretics and underwent right heart catheter- $\overrightarrow{\vec{s}}$ isation before entry into the Medical ResearchCouncil trial of long-term oxygen therapy. None $\frac{}{0}$ of the patients received oxygen or bronchodila-क tors in the 24 hours preceding the investigation. All gave informed consent to the procedure.

PULMONARY FUNCTION TESTS

Pulmonary function was measured on the day

Table 1 Details of patients studied

\begin{tabular}{|c|c|c|c|c|c|c|c|c|}
\hline Patient & Age & $H t(m)$ & $W t(k g)$ & $T L C(l)$ & $R V(l)$ & $F E V_{1}(l)$ & $\begin{array}{l}F E V_{1} / F V C \\
(\%)\end{array}$ & $\begin{array}{l}\text { DLco } \\
(\mathrm{mmol} / \mathrm{min} / k \mathrm{~Pa})\end{array}$ \\
\hline $\mathbf{W N}$ & 64 & $1 \cdot 67$ & $81 \cdot 5$ & $\begin{array}{l}5 \cdot 38 \\
(5 \cdot 95)\end{array}$ & $\begin{array}{l}3 \cdot 28 \\
(2 \cdot 15)\end{array}$ & $\begin{array}{l}0.67 \\
(2 \cdot 65)\end{array}$ & $\begin{array}{l}32 \\
(68)\end{array}$ & $\begin{array}{l}3 \cdot 0 \\
(8 \cdot 3)\end{array}$ \\
\hline GB & 60 & $1 \cdot 77$ & $59 \cdot 5$ & $\begin{array}{l}6 \cdot 10 \\
(6 \cdot 90)\end{array}$ & $\begin{array}{l}3 \cdot 14 \\
(2 \cdot 35)\end{array}$ & $\begin{array}{l}0.97 \\
(3.12)\end{array}$ & $\begin{array}{l}30 \\
(69)\end{array}$ & $\begin{array}{l}4 \cdot 2 \\
(9 \cdot 3)\end{array}$ \\
\hline AT & 69 & $1 \cdot 68$ & $54 \cdot 0$ & $\begin{array}{l}7 \cdot 17 \\
(6 \cdot 05)\end{array}$ & $\begin{array}{l}4 \cdot 23 \\
(2 \cdot 25)\end{array}$ & $\begin{array}{l}0.89 \\
(2.52)\end{array}$ & $\begin{array}{l}44 \\
(66)\end{array}$ & $\begin{array}{l}4 \cdot 9 \\
(7 \cdot 7)\end{array}$ \\
\hline JR & 47 & $1 \cdot 63$ & 73.0 & $\begin{array}{l}6 \cdot 31 \\
(5 \cdot 60)\end{array}$ & $\begin{array}{l}4 \cdot 26 \\
(1 \cdot 75)\end{array}$ & $\begin{array}{l}0.59 \\
(3.02)\end{array}$ & $\begin{array}{l}36 \\
(74)\end{array}$ & $\begin{array}{l}3 \cdot 2 \\
(8 \cdot 7)\end{array}$ \\
\hline WJ & 44 & $1 \cdot 68$ & $51 \cdot 0$ & $\begin{array}{l}5 \cdot 94 \\
(6 \cdot 00)\end{array}$ & $\begin{array}{l}3 \cdot 40 \\
(1 \cdot 80)\end{array}$ & $\begin{array}{l}0.46 \\
(3 \cdot 30)\end{array}$ & $\begin{array}{l}24 \\
(75)\end{array}$ & $\begin{array}{l}2 \cdot 1 \\
(9 \cdot 4)\end{array}$ \\
\hline VS & 59 & 1.65 & $62 \cdot 0$ & $\begin{array}{l}5 \cdot 30 \\
(5 \cdot 80)\end{array}$ & $\begin{array}{l}1 \cdot 75 \\
(2 \cdot 00)\end{array}$ & $\begin{array}{l}0.53 \\
(2 \cdot 72)\end{array}$ & $\begin{array}{l}25 \\
(70)\end{array}$ & $\begin{array}{l}2 \cdot 4 \\
(8 \cdot 0)\end{array}$ \\
\hline FM & 61 & $1 \cdot 68$ & $82 \cdot 0$ & $\begin{array}{l}7 \cdot 63 \\
(6 \cdot 10)\end{array}$ & $\begin{array}{l}4 \cdot 85 \\
(2 \cdot 10)\end{array}$ & $\begin{array}{l}0 \cdot 50 \\
(2 \cdot 76)\end{array}$ & $\begin{array}{l}28 \\
(69)\end{array}$ & $\begin{array}{l}6 \cdot 9 \\
(8 \cdot 0)\end{array}$ \\
\hline HB & 49 & $1 \cdot 66$ & $75 \cdot 5$ & $\begin{array}{l}5 \cdot 02 \\
(5 \cdot 80)\end{array}$ & $\begin{array}{l}2 \cdot 15 \\
(1 \cdot 85)\end{array}$ & $\begin{array}{l}0.69 \\
(3 \cdot 08)\end{array}$ & $\begin{array}{l}38 \\
(74)\end{array}$ & $\begin{array}{l}2 \cdot 3 \\
(8 \cdot 9)\end{array}$ \\
\hline $\mathbf{H J}$ & 49 & $1 \cdot 80$ & $55 \cdot 5$ & $\begin{array}{l}8 \cdot 35 \\
(7 \cdot 10)\end{array}$ & $\begin{array}{l}4 \cdot 43 \\
(2 \cdot 25)\end{array}$ & $\begin{array}{l}0.80 \\
(3 \cdot 58)\end{array}$ & $\begin{array}{l}25 \\
(74)\end{array}$ & $\begin{array}{l}2 \cdot 2 \\
(10 \cdot 4)\end{array}$ \\
\hline LW & 56 & $1 \cdot 79$ & $91 \cdot 0$ & $\begin{array}{l}6 \cdot 34 \\
(7 \cdot 00)\end{array}$ & $\begin{array}{l}3 \cdot 25 \\
(2 \cdot 35)\end{array}$ & $\begin{array}{l}0.99 \\
(3 \cdot 32)\end{array}$ & $\begin{array}{l}46 \\
(71)\end{array}$ & $\begin{array}{l}2 \cdot 8 \\
(9 \cdot 8)\end{array}$ \\
\hline
\end{tabular}

TLC = total lung capacity; RV = residual volume; $F E V_{1}=$ forced expired volume in one second; FVC = forced vital capacity; DLco = transfer factor for carbon monoxide. All volumes are corrected to BTPS. The patient's weight (Wt) and height (Ht) are shown and values in parentheses are those predicted for the patient's age and height (Cotes, 1975).

Table 2 Response to terbutaline

\begin{tabular}{|c|c|c|c|c|c|c|c|c|c|c|c|c|}
\hline Patient & $\begin{array}{l}\text { Dose of } \\
\text { terbutaline } \\
(\mu g)\end{array}$ & & $\begin{array}{l}\text { Heart rate } \\
\text { (beats/min) }\end{array}$ & $\begin{array}{l}\text { Cardiac } \\
\text { index } \\
\left(l / \min / m^{2}\right)\end{array}$ & $\begin{array}{l}P A P \\
(m m H g)\end{array}$ & $\begin{array}{l}P W P \\
(m m H g)\end{array}$ & $\begin{array}{l}P V R \\
\left(\text { dyne } / \mathrm{s} / \mathrm{cm}^{5}\right)\end{array}$ & $\begin{array}{l}B A P \\
(m m H g)\end{array}$ & $\begin{array}{l}\text { Ventilatory } \\
\text { index } \\
\left(\mathrm{l} / \mathrm{min} / \mathrm{m}^{2}\right)\end{array}$ & $\begin{array}{l}P E F R \\
(l / s)\end{array}$ & $\begin{array}{l}\mathrm{PaO}_{2} \\
(\mathrm{mmHg})\end{array}$ & $\begin{array}{l}\mathrm{PaCO}_{2} \\
(\mathrm{mmHg})\end{array}$ \\
\hline WN & 115 & $\begin{array}{l}\mathrm{C} \\
\mathrm{T}\end{array}$ & $\begin{array}{l}98 \\
(99)\end{array}$ & $\begin{array}{l}3 \cdot 07 \\
(3 \cdot 82)\end{array}$ & $\begin{array}{l}31 \\
(30)\end{array}$ & $\begin{array}{l}4 \\
(4)\end{array}$ & $\begin{array}{l}366 \\
(283)\end{array}$ & $\begin{array}{l}85 \\
(89)\end{array}$ & $\begin{array}{l}3 \cdot 75 \\
(4.32)\end{array}$ & $\begin{array}{l}1 \cdot 8 \\
(1.9)\end{array}$ & $\begin{array}{l}47 \cdot 3 \\
(48 \cdot 1)\end{array}$ & $\begin{array}{l}58 \cdot 6 \\
(55 \cdot 9)\end{array}$ \\
\hline GB & 80 & C & $\begin{array}{l}89 \\
(90)\end{array}$ & $\begin{array}{l}4 \cdot 67 \\
(5 \cdot 79)\end{array}$ & $\begin{array}{l}24 \\
(22)\end{array}$ & $\begin{array}{l}4 \\
(2)\end{array}$ & $\begin{array}{l}201 \\
(162)\end{array}$ & $\begin{array}{l}109 \\
(89)\end{array}$ & $\begin{array}{l}2 \cdot 97 \\
(4 \cdot 88)\end{array}$ & $\begin{array}{l}2 \cdot 4 \\
(2 \cdot 3)\end{array}$ & $\begin{array}{l}55 \cdot 4 \\
(56 \cdot 1)\end{array}$ & $\begin{array}{l}49 \cdot 7 \\
(39 \cdot 3)\end{array}$ \\
\hline $\mathbf{A T}$ & 75 & $\begin{array}{l}\mathrm{C} \\
\mathrm{T}\end{array}$ & $\begin{array}{l}63 \\
(72)\end{array}$ & $\begin{array}{l}2 \cdot 39 \\
(2 \cdot 71)\end{array}$ & $\begin{array}{l}27 \\
(29)\end{array}$ & $\begin{array}{l}7 \\
\text { (7) }\end{array}$ & $\begin{array}{l}424 \\
(413)\end{array}$ & $\begin{array}{l}70 \\
(70)\end{array}$ & $\begin{array}{l}4 \cdot 52 \\
(5 \cdot 45)\end{array}$ & $\begin{array}{l}2 \cdot 2 \\
(2 \cdot 3)\end{array}$ & $\begin{array}{l}57 \cdot 0 \\
(59 \cdot 6)\end{array}$ & $\begin{array}{l}50 \cdot 3 \\
(51 \cdot 0)\end{array}$ \\
\hline $\mathbf{J R}$ & 100 & $\begin{array}{l}\mathrm{C} \\
\mathrm{T}\end{array}$ & $\begin{array}{l}88 \\
(96)\end{array}$ & $\begin{array}{l}2 \cdot 81 \\
(3 \cdot 25)\end{array}$ & $\begin{array}{l}53 \\
(54)\end{array}$ & $\begin{array}{l}5 \\
(5)\end{array}$ & $\begin{array}{l}764 \\
(674)\end{array}$ & $\begin{array}{l}86 \\
(82)\end{array}$ & $\begin{array}{l}5 \cdot 30 \\
(5 \cdot 25)\end{array}$ & $\begin{array}{l}1 \cdot 2 \\
(1 \cdot 2)\end{array}$ & $\begin{array}{l}46 \cdot 0 \\
(44 \cdot 5)\end{array}$ & $\begin{array}{l}56 \cdot 0 \\
(55 \cdot 4)\end{array}$ \\
\hline WJ & 70 & $\mathrm{C}$ & $\begin{array}{l}114 \\
(114)\end{array}$ & $\begin{array}{l}2 \cdot 53 \\
(2 \cdot 88)\end{array}$ & $\begin{array}{l}61 \\
(66)\end{array}$ & $\begin{array}{l}6 \\
(8)\end{array}$ & $\begin{array}{l}1139 \\
(1056)\end{array}$ & $\begin{array}{l}90 \\
(85)\end{array}$ & $\begin{array}{l}5 \cdot 24 \\
(4 \cdot 68)\end{array}$ & $\begin{array}{l}1 \cdot 3 \\
(1 \cdot 3)\end{array}$ & $\begin{array}{l}35 \cdot 7 \\
(39 \cdot 4)\end{array}$ & $\begin{array}{l}55 \cdot 7 \\
(49 \cdot 3)\end{array}$ \\
\hline VS & 85 & C & $\begin{array}{l}93 \\
(99)\end{array}$ & $\begin{array}{l}4 \cdot 67 \\
(4 \cdot 89)\end{array}$ & $\begin{array}{l}27 \\
(30)\end{array}$ & 8 & $\begin{array}{l}193 \\
(242)\end{array}$ & $\begin{array}{l}135 \\
(125)\end{array}$ & $\begin{array}{l}6 \cdot 40 \\
(5 \cdot 97)\end{array}$ & $\begin{array}{l}1 \cdot 6 \\
(1 \cdot 3)\end{array}$ & $\begin{array}{l}71 \cdot 0 \\
(70 \cdot 0)\end{array}$ & $\begin{array}{l}37 \cdot 5 \\
(39 \cdot 0)\end{array}$ \\
\hline $\mathbf{F M}$ & 115 & $\begin{array}{l}\mathrm{C} \\
\mathrm{T}\end{array}$ & $\begin{array}{l}78 \\
(87)\end{array}$ & $\begin{array}{l}4 \cdot 23 \\
(5 \cdot 18)\end{array}$ & $\begin{array}{l}25 \\
(28)\end{array}$ & $\begin{array}{l}10 \\
(10)\end{array}$ & $\begin{array}{l}148 \\
(145)\end{array}$ & $\begin{array}{l}99 \\
(93)\end{array}$ & $\begin{array}{l}3.07 \\
(3.11)\end{array}$ & $\begin{array}{l}1 \cdot 5 \\
(1 \cdot 6)\end{array}$ & $\begin{array}{l}50 \cdot 7 \\
(47 \cdot 7)\end{array}$ & $\begin{array}{l}50 \cdot 5 \\
(51 \cdot 2)\end{array}$ \\
\hline HB & 250 & $\mathrm{C}$ & $\begin{array}{l}81 \\
(90)\end{array}$ & $\begin{array}{l}3.47 \\
(6.05)\end{array}$ & $\begin{array}{l}42 \\
(38)\end{array}$ & $\begin{array}{l}7 \\
(6)\end{array}$ & $\begin{array}{l}440 \\
(231)\end{array}$ & $\begin{array}{l}86 \\
(86)\end{array}$ & $\begin{array}{l}2 \cdot 77 \\
(3 \cdot 35)\end{array}$ & $\begin{array}{l}2 \cdot 2 \\
(2 \cdot 2)\end{array}$ & $\begin{array}{l}48 \cdot 0 \\
(45 \cdot 5)\end{array}$ & $\begin{array}{l}40 \cdot 1 \\
(47 \cdot 3)\end{array}$ \\
\hline HJ & 250 & $\begin{array}{l}\mathrm{C} \\
\mathrm{T}\end{array}$ & $\begin{array}{l}69 \\
(78)\end{array}$ & $\begin{array}{l}3.49 \\
(4.89)\end{array}$ & $\begin{array}{l}32 \\
(26)\end{array}$ & $\begin{array}{l}3 \\
(3)\end{array}$ & $\begin{array}{l}388 \\
(220)\end{array}$ & $\begin{array}{l}93 \\
(76)\end{array}$ & $\begin{array}{l}3 \cdot 34 \\
(4 \cdot 11)\end{array}$ & $\begin{array}{l}1 \cdot 8 \\
(2 \cdot 1)\end{array}$ & $\begin{array}{l}52 \cdot 5 \\
(57 \cdot 0)\end{array}$ & $\begin{array}{l}42 \cdot 8 \\
(35 \cdot 6)\end{array}$ \\
\hline LW & 250 & $\begin{array}{l}\mathrm{C} \\
\mathrm{T}\end{array}$ & $\begin{array}{l}78 \\
(99)\end{array}$ & $\begin{array}{l}3 \cdot 70 \\
(4 \cdot 73)\end{array}$ & $\begin{array}{l}46 \\
(50)\end{array}$ & $\begin{array}{l}9 \\
\text { (9) }\end{array}$ & $\begin{array}{l}382 \\
(330)\end{array}$ & $\begin{array}{l}92 \\
(87)\end{array}$ & $\begin{array}{l}5 \cdot 19 \\
(5 \cdot 56)\end{array}$ & $\begin{array}{l}2 \cdot 5 \\
(2 \cdot 7)\end{array}$ & $\begin{array}{l}48 \cdot 0 \\
(50 \cdot 0)\end{array}$ & $\begin{array}{l}45 \cdot 0 \\
(37 \cdot 9)\end{array}$ \\
\hline Mean & & & $\begin{array}{l}85 \cdot 1 \\
(92 \cdot 4)\end{array}$ & $\begin{array}{l}3 \cdot 50 \\
(4 \cdot 42)\end{array}$ & $\begin{array}{l}36 \cdot 8 \\
(37 \cdot 3)\end{array}$ & $\begin{array}{l}6 \cdot 3 \\
(5 \cdot 9)\end{array}$ & $\begin{array}{l}445 \\
(376)\end{array}$ & $\begin{array}{l}94 \cdot 5 \\
(88 \cdot 2)\end{array}$ & $\begin{array}{l}4 \cdot 36 \\
(4 \cdot 67)\end{array}$ & $\begin{array}{l}1.8 \\
(1.9)\end{array}$ & $\begin{array}{l}51 \cdot 2 \\
(51 \cdot 8)\end{array}$ & $\begin{array}{l}48 \cdot 6 \\
(46 \cdot 2)\end{array}$ \\
\hline SD & & & $\begin{array}{l}14 \cdot 7 \\
(11 \cdot 9)\end{array}$ & $\begin{array}{l}0.83 \\
(1 \cdot 19)\end{array}$ & $\begin{array}{l}13 \cdot 0 \\
(14 \cdot 5)\end{array}$ & $\begin{array}{l}2 \cdot 3 \\
(2 \cdot 6)\end{array}$ & $\begin{array}{l}300 \\
(284)\end{array}$ & $\begin{array}{l}17 \cdot 4 \\
(14 \cdot 6)\end{array}$ & $\begin{array}{l}1 \cdot 17 \\
(0 \cdot 95)\end{array}$ & $\begin{array}{l}0 \cdot 5 \\
(0 \cdot 5)\end{array}$ & $\begin{array}{l}9 \cdot 1 \\
(8 \cdot 9)\end{array}$ & $\begin{array}{l}7 \cdot 1 \\
(7 \cdot 6)\end{array}$ \\
\hline
\end{tabular}

The total dose of terbutaline given is shown together with the resting heart rate, cardiac index, mean pulmonary artery pressure (PAP), mear $\Omega$ pulmonary wedge pressure (PWP), mean brachial artery pressure (BAP), pulmonary vascular resistance (PVR), ventilatory index, peak expiratorye flow rate (PEFR), and arterial oxygen and carbon dioxide tensions $\left(\mathrm{PaO}_{2}\right.$ and $\mathrm{PaCO}_{2}$ respectively). $\mathrm{C}=$ control values and $\mathrm{T}=$ terbutaline values $\mathrm{O}$ in parentheses. (Note conversion to SI units, $1 \mathrm{~mm}=0 \cdot 133 \mathrm{kPa}$ and $1 \mathrm{dyne} / \mathrm{s} / \mathrm{cm}^{5}=10^{-1} \mathrm{kPa} \mathrm{I}^{-1} \mathrm{~s}^{-1}$ ). 
before cardiac catheterisation. Static lung volumes were measured by spirometry, forced expired volumes from the integrated output of a Fleisch pneumotachograph, and diffusing capacity for carbon monoxide using the single breath method. Total lung capacity was measured using the helium dilution method. The results are summarised in Table 1.

\section{ARTERIAL BLOOD GAS TENSIONS}

Arterial oxygen tension $\left(\mathrm{PaO}_{2}\right)$ and carbon dioxide tension $\left(\mathrm{PaCO}_{2}\right)$ were determined using polythenecovered Radiometer electrodes, calibrated with high and low gas tensions before each measurement. In measurements of tonometered blood, these electrodes gave $95 \%$ confidence limits of $\pm 0.52 \mathrm{kPa} \quad\left(\mathrm{PaO}_{2}\right)$ and $\pm 0.44 \mathrm{kPa} \quad\left(\mathrm{PaCO}_{2}\right)$. Venous admixture was estimated from the shunt equation using the calculated ideal alveolar oxygen tension.

\section{CIRCULATORY STUDIES}

Patients were studied supine in the fasting state. A No. 9 double-lumen Cournand catheter was passed into the pulmonary artery for simultaneous measurement of pulmonary artery pressure (PAP) and pulmonary wedge pressure (PWP). The zero reference point for intravascular pressures was $5 \mathrm{~cm}$ vertically below the manubriosternal angle. A Cournand needle was inserted into the brachial artery to measure pressure and for sampling arterial blood to measure gas tension and oxyhaemoglobin saturation. Cardiac output was measured by the direct Fick method. The patients breathed through a two-way valve for at least 5 minutes before any measurements were made. Expired gas was collected in a Tissot spirometer for 3 minutes and analysed by the Scholander method to determine oxygen uptake and carbon dioxide production. During the period of gas collection pulmonary vascular pressures were recorded and simultaneous samples of mixed venous and arterial blood were taken. Oxyhaemoglobin saturation was measured by a spectrophotometric method. The standard error of a single estimation of cardiac output in the supine position was $8 \cdot 1 \%$.

Pulmonary vascular resistance was calculated from the pressure gradient across the pulmonary vascular bed divided by pulmonary blood flow. All values for cardiac output and ventilation have been corrected for body surface area to give the cardiac and ventilatory index.

Thirty minutes before the measurement of resting cardiac output, peak expiratory flow rate (PEFR) was recorded as the best of three at- tempts, using a Wright peak flow meter. After resting cardiac output had been determined, terbutaline was injected slowly into the pulmonary artery during one minute and the cardiac output was measured again after a further 40 minutes. When all other recordings had been completed the PEFR was measured again.

The significance of any change observed was determined using a paired Student $t$ test.

\section{DOSE OF TERBUTALINE}

The first seven patients were given $1.4 \mu \mathrm{g} / \mathrm{kg}$ terbutaline sulphate. In view of the small changes produced by this initial study, a further group of three patients were given a single bolus of $250 \mu \mathrm{g}$, which is the recommended therapeutic dose.

\section{Results}

The effects of terbutaline on individual patients are shown in Table 2. The PA mean pressure at rest was $24 \mathrm{mmHg}$ or more in all patients. There was no significant change in PAP or PWP, in the group as a whole, after the injection of terbutaline $(\mathrm{P}<0.1$ and $\mathrm{P}<0.2$ respectively).

Cardiac output increased in all patients to a variable extent. In the group as a whole, terbutaline caused a significant increase $(\mathrm{P}<0.0025)$ in cardiac index from a mean value of $3.501 / \mathrm{min} / \mathrm{m}^{2}$ to $4.421 / \mathrm{min} / \mathrm{m}^{2}$. The increase varied from 5 to $24 \%$ in the seven patients who received $1.4 \mu \mathrm{g} / \mathrm{kg}$ terbutaline but was greater in the three patients who received the larger dose $(27-74 \%)$.

The change in cardiac output was accompanied by a significant rise $(\mathrm{P}<0.0005)$ in mean oxygen uptake from $253 \mathrm{ml} / \mathrm{min}$ STPD (SD \pm 32.9$)$ to $284 \mathrm{ml} / \mathrm{min}(\mathrm{SD} \pm 48 \cdot 8)$. The arteriovenous oxygen difference was significantly reduced $(P<0.0025)$, after terbutaline, from a mean value of $42.8 \mathrm{ml} / 1$ STPD (SD \pm 1.03$)$ to $38.5 \mathrm{ml} / 1(\mathrm{SD} \pm 1.05)$.

The heart rate rose significantly $(P<0.0025)$ from 85.1 beats/min to 92.4 beats/min, and stroke index increased $(P<0.0125)$ from a mean value of $42 \cdot 1 \mathrm{ml} / \mathrm{m}^{2}(\mathrm{SD} \pm 10.9)$ to $48.7 \mathrm{ml} / \mathrm{m}^{2}(\mathrm{SD} \pm 14 \cdot 5)$. Pulmonary vascular resistance fell from a mean value of 445 dynes $/ \mathrm{s} / \mathrm{cm}^{5}$ to 376 dynes $/ \mathrm{s} / \mathrm{cm}^{5}$.

There was a small but significant increase of venous admixture effect after the injection of terbutaline $(\mathrm{P}<0.0125)$. The average control value was $35.7 \%(\mathrm{SD} \pm 9.6)$, rising to $38.9 \%$ $(\mathrm{SD} \pm 10.9)$ after administration of the terbutaline. At the same time mixed venous oxygen saturation rose $(\mathrm{P}<0.05)$ from $55.9 \%(\mathrm{SD} \pm 11.0)$ to $58.6 \%(\mathrm{SD} \pm 10 \cdot 6)$.

The $\mathrm{PaO}_{2}$ did not change significantly $(P<0.25)$ from the mean control value of 
$51.2 \mathrm{mmHg}$. The greatest observed fall in $\mathrm{PaO}_{2}$ for any patient was $3.0 \mathrm{mmHg}$ (Table 2). There was a slight but insignificant fall in $\mathrm{PaCO}_{2}$ from a mean value of $48.6 \mathrm{mmHg}$ to $46.2 \mathrm{mmHg}$.

The mean ventilatory index rose from 4.36 $1 / \mathrm{min} / \mathrm{m}^{2}$ to $4.671 / \mathrm{min} / \mathrm{m}^{2}$ following terbutaline $(\mathrm{P}<0.05)$. Similarly, the alveolar ventilatory index rose $(\mathrm{P}<0.05)$ from $1.941 / \mathrm{min} / \mathrm{m}^{2}(\mathrm{SD} \pm 0.36)$ to $2 \cdot 271 / \mathrm{min} / \mathrm{m}^{2}(\mathrm{SD} \pm 0 \cdot 47)$.

There was a significant increase in carbon dioxide production $(\mathrm{P}<0.025)$ following the infusion of terbutaline. The mean value for $\mathrm{CO}_{2}$ production was $189 \mathrm{ml} / \mathrm{min}(\mathrm{SD} \pm 22 \cdot 8)$, rising to $209 \mathrm{ml} / \mathrm{min}(\mathrm{SD} \pm 35.4)$ after the drug was administered.

Peak expiratory flow rate was unchanged, the mean control being $1.8 \mathrm{1} / \mathrm{s}$ and $1.9 \mathrm{l} / \mathrm{s}$ after the terbutaline $(\mathrm{P}<0.25)$. There was a significant fall $(\mathrm{P}<0.025)$ in mean brachial artery pressure from $94.5 \mathrm{mmHg}$ to $88.2 \mathrm{mmHg}$.

\section{Discussion}

Carlström and Westling (1970) and Arner et al. (1970) demonstrated that terbutaline has a marked dose-related effect on the systemic circulation. The purpose of the present study was to assess the effect of terbutaline on the pulmonary circulation in a group of patients with bronchitis who had developed pulmonary vascular disease. In particular, it was considered possible that terbutaline might prove beneficial by reducing pulmonary vascular resistance. The first seven patients received $1.4 \mu \mathrm{g} / \mathrm{kg}$ terbutaline, which results in a free serum level of $2 \mathrm{ng} / \mathrm{ml}$ after 30 minutes (Davies, 1972). This is a slightly lower concentration than the peak level of free drug observed one to three hours after a single oral dose of $5 \mathrm{mg}$ (Nilsson et al., 1972). In view of the small changes observed in these patients the remainder were given a larger total dose $(250 \mu \mathrm{g})$.

After the injection of terbutaline the cardiac output increased, and this was greater in the patients who received $250 \mu \mathrm{g}$, confirming the results obtained by Arner et al. (1970) in normal subjects. This increase may be either the result of $\beta_{1}$ adrenergic stimulation by the drug, or a reflex response to systemic hypotension following the fall in systemic vascular resistance due to $\beta_{2}$ adrenergic stimulation (Gibson and Coltart, 1971).

In the initial study a small dose of terbutaline was used in an attempt to minimise the $\beta_{1}$ adrenergic effects. However, an increase in cardiac output occurred despite this low dose, and mean brachial artery pressure fell, suggesting a decrease in the peripheral vascular resistance. This, together

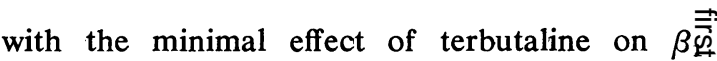
adrenergic receptors in vitro (Persson and Johne son, 1970), suggests that the increase in cardiaco output was mainly secondary to its $\beta_{2}$ adrenergie activity.

Despite the increase in cardiac output pula monary arterial pressure remained unaltered owing to a fall in PVR. The relation between pul? monary blood flow and vascular resistance in $\vec{\omega}$ chronic bronchitis was studied by Harris et alo (1968), who demonstrated a $38 \%$ reduction in PVR when blood flow was doubled. This was conew sidered to be the result of distension or recruit ${ }_{G}^{N}$ ment of pulmonary vessels. It is, thereforeos probable that the fall in PVR with terbutaline was mainly due to the increased cardiac output rathe巳 than to drug induced vasodilatation.

Previous work by Halmagyi and Cotes (1959ס and Harris (1970) suggested that agents affecting the pulmonary circulation may adversely affecD the ventilation to perfusion ratio, resulting in an increase in venous admixture. The present stude demonstrated a small but significant increase in venous admixture following the injection of ter믕 butaline. Despite this increase there was no alteration in $\mathrm{PaO}_{2}$, probably because of the associated rise in mixed venous oxygen saturationळ Alveolar ventilation increased in proportion to the increased carbon dioxide production, arteria carbon dioxide tension remaining unaltered.

It is concluded that intravenous terbutaline in therapeutic doses has no major effect upon the्] pulmonary circulation in patients with chronic bronchitis. Although venous admixture was slightly increased there was no fall in arteria兂 oxygen tension.

We thank Miss J. Blackhall, Staff Nurse M. Boothô and Mr. B. J. Milton for technical assistance, and Mrs. B. Bennett for typing the manuscript.

\section{References}

Arner, B. (1970). A comparative clinical trial of dif ferent subcutaneous doses of terbutaline and orciprenaline in bronchial asthma. Acta Medica. Scandinavica, Supplement 512, 45-48.

Arner, B., Bertler, A., Karlefors, T., and Westling. (1970). Circulatory effects of orciprenaline, adrena line and a new sympathomimetic $\beta$-receptor stimulating agent, terbutaline, in normal human subjects. Acta Medica Scandinavica, Supplemen 5 512, 25-32.

Carlström, S. (1970). Introductory remarks (to studie@ on terbutaline). Acta Medica Scandinavica, Supple $\varrho$ ment 512, 7-9.

Carlström, S., and Westling. H. (1970). Metabolic

\section{,}


circulatory and respiratory effects of a new sympathomimetic $\beta$-receptor-stimulating agent, terbutaline, compared with those of orciprenaline. Acta Medica Scandinavica, Supplement 512, 33-40.

Cotes, J. E. (1975). Lung Function, 3rd edition, pp. 386-387. Blackwell Scientific Publications, Oxford.

Davies, D. S. (1972). Metabolism of adrenaline like bronchodilator drugs. Proceedings of United Kingdom-Scandinavian Conference on Bronchodilation, pp. 87-99. Astra Chemicals Limited, Watford.

Freedman, B. J. (1971). Trial of new bronchodilator, terbutaline, in asthma. British Medical Journal, 1, 633-636.

Gibson, D. G., and Coltart, D. J. (1971). Haemodynamic effects of intravenous salbutamol in patients with mitral valve disease: comparison with isoprenaline and atropine. Postgraduate Medical Journal 47, Supplement (Salbutamol), 40-44.

Halmagyi, D. F., and Cotes, J. E. (1959). Reduction in systemic blood oxygen as a result of procedures affecting the pulmonary circulation in patients with chronic pulmonary disease. Clinical Science, 18, 475-489.

Harris, L. H. (1970). Effects of isoprenaline plus phenylephrine by pressurized aerosol on blood gases, ventilation, and perfusion in chronic obstructive lung disease. British Medical Journal, 4, 579-582.

Harris, L. (1973). Comparison of cardiorespiratory effects of terbutaline and salbutamol aerosols in patients with reversible airways obstruction. Thorax, 28, 592-595.

Harris, P., Segel, N., and Bishop, J. M. (1968). The relation between pressure and flow in the pulmonary circulation in normal subjects and in patients with chronic bronchitis and mitral stenosis. Cardiovascular Research, 2, 73-83.

Koch, G. (1972). Terbutaline in bronchial asthma. Effect on lung volumes, ventilatory performance, pulmonary gas exchange and circulation at rest and during exercise. Scandinavian Journal of Respiratory Disease, 53, 187-195.

Legge, J. S., Gaddie, J., and Palmer, K. N. V. (1971). Comparison of two oral selective $\beta_{2}$-adrenergic stimulant drugs in bronchial asthma. British Medical Journal, 1, 637-639.

Nilsson, H. T., Persson, K., and Tegnér, K. (1972). The metabolism of terbutaline in man. Xenobiotica, 2, 363-375.

Persson, H., and Johnson, B. (1970). A dual preparation technique for studying the differentiation of the effect of sympathomimetic agents on heart and tracheal muscle. Acta Medica Scandinavica, Supplement 512, 21-24.

Requests for reprints to: Dr. R. A. Stockley, Department of Medicine, Queen Elizabeth Hospital, Edgbaston, Birmingham B15 2TH, UK. 